\title{
THE USE OF NEUTRON ACTIVATION ANALYSIS IN THE BIOMONITORING OF TRACE ELEMENT DEPOSITION IN THE OPOLE PROVINCE
}

\author{
WYKORZYSTANIE NEUTRONOWEJ ANALIZY AKTYWACYJNEJ \\ W BIOMONITORINGU DEPOZYCJI PIERWIASTKÓW ŚLADOWYCH \\ W WOJEWÓDZTWIE OPOLSKIM
}

\begin{abstract}
The neutron activation analysis procedure was used to determine the concentration of 42 elements: Na, $\mathrm{Mg}, \mathrm{Al}, \mathrm{Cl}, \mathrm{K}, \mathrm{Ca}, \mathrm{Sc}, \mathrm{V}, \mathrm{Cr}, \mathrm{Mn}, \mathrm{Fe}, \mathrm{Ni}, \mathrm{Co}, \mathrm{Zn}, \mathrm{As}, \mathrm{Se}, \mathrm{Br}, \mathrm{Rb}, \mathrm{Sr}, \mathrm{Zr}, \mathrm{Nb}, \mathrm{Mo}, \mathrm{I}, \mathrm{Ag}, \mathrm{Cd}, \mathrm{Sb}, \mathrm{Ba}, \mathrm{Cs}, \mathrm{La}, \mathrm{Ce}$, $\mathrm{Nd}, \mathrm{Sm}, \mathrm{Eu}, \mathrm{Tb}, \mathrm{Yb}, \mathrm{Hf}, \mathrm{Ta}, \mathrm{W}, \mathrm{Au}, \mathrm{Hg}$, Th, and U accumulated in mosses sampled for testing in September and October 2011 in the Opole Province (Southern Poland). Samples of different moss species were collected near the intersections of the grid lines marked on the map of the province. The distance between the points was approximately $20 \mathrm{~km}$. The analysis of the results made it possible to identify the places of increased deposition of element-pollutants and to indicate the potential sources of emission. Factor analysis revealed four components, two of which are of definite anthropogenic origin. The possible sources of elements are local industry and farming, and distant heavy industry complexes. The results have demonstrated the increased content of $\mathrm{Cr}, \mathrm{Cd}$, $\mathrm{Hg}$, and $\mathrm{U}$ in moss samples collected in agricultural areas located in the southern part of the province. It has been concluded that the industrial areas of Rybnik and Ostrava and Karvina Coal Basin may be the potential source of emission of these elements.
\end{abstract}

Keywords: neutron activation analysis (NAA), mosses, biomonitoring, Southern Poland

\section{Introduction}

The knowledge of elemental composition of the environmental compartments (air, water and soil) is one of the main issues of the assessment of the environmental pollution. Particular attention is paid to heavy metals which are mostly harmful to the environment and human health. Such metals as $\mathrm{Cd}, \mathrm{Hg}$ and $\mathrm{Pb}$ are known for their highly toxic properties.

\footnotetext{
${ }^{1}$ Chair of Biotechnology and Molecular Biology, Opole University, ul. kard. B. Kominka 6, 45-032 Opole, Poland, phone +48 7740160 42, fax +48 7740160 50, email: aklos@ uni.opole.pl, mrajfur@o2.pl

${ }^{2}$ Department of Neutron Activation Analysis and Applied Research, Division of Nuclear Physics, Frank Laboratory of Neutron Physics, Joint Institute for Nuclear Research, Joliot-Curie 6, 141980 Dubna, Moscow Region, Russian Federation, email: beataa@gmail.com, marina@nf.jinr.ru

*Corresponding author: aklos@uni.opole.pl
} 
Heavy metals are primarily obtained from the lithosphere intentionally in the course of their planned mining and accidentally while extracting other resources, especially fuels. They are also released into the atmosphere as a result of natural processes, such as volcanic eruptions.

Modern methods of assessment of the environmental pollution more and more often involve living organisms which respond to changes in the chemical composition of their habitat $[1,2]$. Lichens and mosses are most often mentioned as the organisms indicating the presence of pollutants in the atmospheric aerosol [3, 4]. The biomonitoring research involves the analysis of the chemical composition of lichens and/or mosses collected from their natural habitat.

Since 1990, many European countries have been conducting regular (every five years) atmospheric deposition studies of trace elements based on moss analysis. Since 2001, this research has been conducted under the International Cooperative Programme on Effects of Air Pollution on Natural Vegetation and Crops [5]. The programme is coordinated by ICP Vegetation Coordination Centre, Centre for Ecology and Hydrology, Bangor, UK. In 2010/2011, 25 countries, including Poland, participated in the programme [6]. One of the objectives of this research is to assess temporary environmental pollution changes [7-9]. Similar research was conducted in 2000 in the Visegrad Group countries (Hungary, Czech Republic, Poland and Slovakia) [10].

The presented research constitutes a repeated biomonitoring study conducted in the Opole Province in 2005 under the ICP Vegetation project. Its objective is to assess the pollution of the Opole Province (Poland) with trace elements, to attempt to identify their sources and to assess temporary changes in the deposition of pollutants in the area covered by the research.

\section{Materials and methods}

\section{The study area}

The area of the Opole Province is $9.412 \mathrm{~km}^{2}$. Given the prevalence of southern and western winds, the level of the deposition of pollutants in the province is affected by urban and industrial emissions from Opole, Brzeg and Strzelce Opolskie, including the emissions from the cement and limestone industry (Cementownia Odra S.A. in Opole and Gorazdze Cement S.A.), steelworks in Zawadzkie (in liquidation) and in Ozimek, and distant sources of emissions, including those from the southern and western Czech Republic. The local low emission from small factories and towns located in this region is also of relevance. From the south-eastern side, there are coke works in Zdzieszowice, chemical plants in Kedzierzyn-Kozle, then the Rybnik Coal Basin and the Ostrava and Karvina Coal Basin (Ostravskokarvinska uhelna pánev) in the Czech Republic and, moving to the east, Gornoslaski Okreg Przemyslowy (GOP) [Upper Silesian Industrial Region]. The increased deposition of zinc in the province is due to, inter alia, the production of cement. According to data of Krajowe Centrum Inwentaryzacji Emisji [National Emission Centre] [11], the average zinc emission factor for cement plants per unit of cement produced is $0.293 \mathrm{~kg} /$ thousands of tonnes of cement produced. Additionally, $\mathrm{As}, \mathrm{Cr}, \mathrm{Ni}$ and $\mathrm{Cu}$ are emitted $(0.012,0.105,0.111$ and $3.0 \mathrm{~kg}$ per thousands of $\mathrm{Mg}$ (tonnes) of incinerated waste, respectively).

The average annual wet deposition of heavy metals in the Opole Province in 2009 was as follows: $\mathrm{Mn} 4.9 \mathrm{mg} /\left(\mathrm{m}^{2} \cdot\right.$ year $), \mathrm{Ni} 0.70 \mathrm{mg} /\left(\mathrm{m}^{2} \cdot\right.$ year $), \mathrm{Cu} 0.57\left(\mathrm{mg} / \mathrm{m}^{2} \cdot\right.$ year $), \mathrm{Zn}$ 
$45 \mathrm{mg} /\left(\mathrm{m}^{2} \cdot\right.$ year $), \mathrm{Cd} 0.28 \mathrm{mg} /\left(\mathrm{m}^{2} \cdot\right.$ year $)$ and $\mathrm{Pb} 2.1 \mathrm{mg} /\left(\mathrm{m}^{2} \cdot\right.$ year $)$, while at the beginning of the decade the average wet deposition of charges of cadmium $\left(0.44 \mathrm{mg} /\left(\mathrm{m}^{2} \cdot\right.\right.$ year $)$ in 2001 and $0.32 \mathrm{mg} /\left(\mathrm{m}^{2}\right.$. year $)$ in 2002$)$ and lead $\left(7.48 \mathrm{mg} /\left(\mathrm{m}^{2} \cdot\right.\right.$ year $)$ in 2001 and $3.1 \mathrm{mg} /\left(\mathrm{m}^{2} \cdot\right.$ year $)$ in 2002$)$ in the Opole Province was significantly higher than the median value determined for Poland [12].

In the period between 2001 and 2005 and in 2011, the content of $\mathrm{Ni}, \mathrm{As}, \mathrm{Cd}$ and $\mathrm{Pb}$ in particulate matter was analysed in the province. Table 1 shows lower and upper assessment thresholds for concentrations of metals being determined [13, 14].

Table 1

The upper and lower assessment thresholds for the content of $\mathrm{Ni}, \mathrm{As}, \mathrm{Cd}$ and $\mathrm{Pb}$ in particulate matter sampled for testing in the Opole Province

\begin{tabular}{|c|c|c|c|c|}
\hline \multirow{2}{*}{ Years } & $\mathbf{N i}$ & As & Cd & $\mathbf{P b}$ \\
\hline & \multicolumn{3}{|c|}{$\left[\mathrm{ng} / \mathrm{m}^{3}\right]$} & {$\left[\mu \mathrm{g} / \mathrm{m}^{3}\right]$} \\
\hline 2001-2005 & $10-14$ & 2.4-3.6 & $2-3$ & $0.025-0.035$ \\
\hline 2011 & $1.8-4.2$ & $1.48-2.99$ & $0.28-0.49$ & $0.0074-0.0124$ \\
\hline
\end{tabular}

The results presented in the Table show that in 2011, as compared to the period between 2001 and 2005, the content of the analysed metals in particulate matter significantly decreased.

\section{Methods of collecting and preparing samples}

The moss samples were collected in September and October 2011 according to the UNECE ICP Vegetation guidelines, in the closest vicinity of the intersections of meridians and parallels of latitude of the grid marked on the map of the Opole Province (Fig. 1).

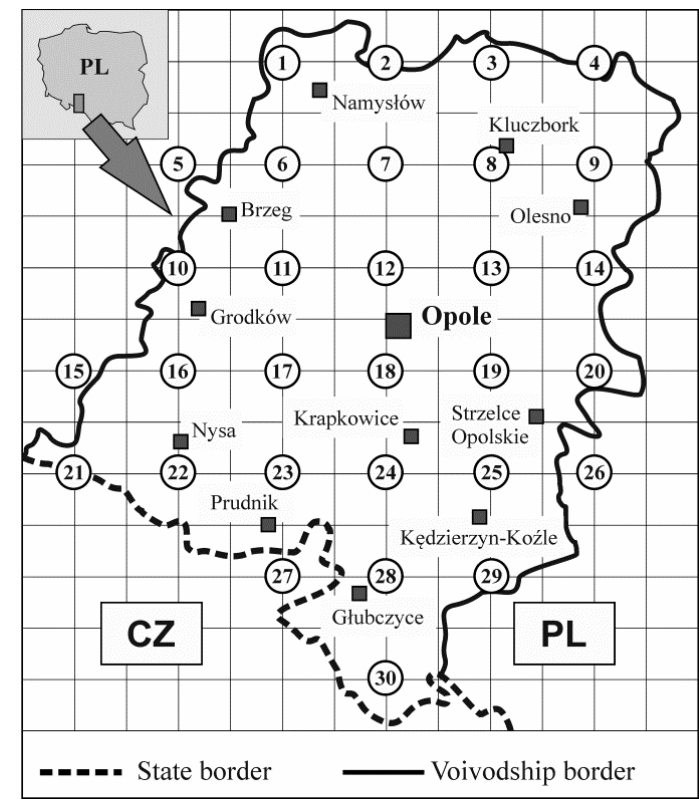

Fig. 1. Sampling sites 
Various moss species were used for testing: Pleurozium schreberi (11 samples) Brachythecium sp. (6), Hypnum cupressiforme (5), Climacium dendroides (2), Polytrichum commune Hedw. (2), Pseudoscleropodium purum (1), Pagiomnium undulatum (1), Hylocomium splendens (1) and Plagiomnium affine (1). The large variety of moss species collected in the sampled area is a result of absence in non forested sites of usually accepted moss biomonitors such as Pleurozium schreberi, Hylocomium splendens and Hypnum cupressiforme.

Approximately $5 \mathrm{~g}$ of mosses were collected at each site. The samples were cleaned of extraneous materials. The green-brownish parts of mosses were used for analysis. Having been dried at $313 \mathrm{~K}$, they were homogenised in an agate mortar. The homogenised moss samples (approximately $2 \mathrm{~g}$ ) were subject to Neutron Activation Analysis (NAA).

\section{Analysis}

Neutron activation analysis was performed at the pulsed fast reactor IBR-2 at the Frank Laboratory of Neutron Physics, JINR, Dubna, Russia. Characteristics of neutron flux density in the two irradiation channels equipped with the pneumatic system and registration of gamma spectra can be found elsewhere [15]. Pelleted samples with masses of around $0.3 \mathrm{~g}$ were heat-sealed in polyethylene foil bags for short time irradiation and in aluminium cups for long time irradiation. To determine long lived isotopes: $\mathrm{Na}, \mathrm{Sc}, \mathrm{Cr}, \mathrm{Fe}, \mathrm{Co}, \mathrm{Ni}, \mathrm{Zn}$, As, Se, Rb, Sr, Zr, Mo, Sb, Cs, Ba, La, Ce, Sm, Eu, Tb, Dy, Hf, Ta, W, Th, and U, cadmium screened channel 1 was used. Samples were irradiated for 100 hours and repacked and measured, using high purity germanium detectors, twice, after 4-5 days and 20-23 days of decay. Measurement time was $45 \mathrm{~min}$ and 2 hours respectively. To determine short lived isotopes $\mathrm{Mg}, \mathrm{Al}, \mathrm{Cl}, \mathrm{K}, \mathrm{Ca}, \mathrm{Ti}, \mathrm{V}, \mathrm{Mn}, \mathrm{Br}$ and $\mathrm{I}$ irradiation channel 2 was used. Samples were irradiated for $3 \mathrm{~min}$ and measured twice after 3-5 min and $20 \mathrm{~min}$ of decay for $3 \mathrm{~min}$ and 9-10 min respectively. Element contents were determined on the basis of certified reference materials and flux comparators. The gamma-spectra of the induced activity were analysed using software developed in the Frank Laboratory of Neutron Physics [16].

\section{Quality control}

The quality control of NAA results was ensured by simultaneous analysis of the examined samples and reference materials: marine sediments 433 IAEA (International Atomic Energy Agency), coal 1632c and soil 2709 NIST (National Institute of Standards and Technology, USA). The measured concentrations were in good agreement with the recommended values.

\section{Results and discussion}

Table 2 shows the medians, mean values and standard deviations of element concentrations in mosses.

Significant differences between the median and the mean value and a significant standard deviation with reference to the mean value imply diverse distribution of concentrations of the tested analytes. Examples of such distributions include the following: $\mathrm{Au}$ (min.: $0.007 \mathrm{mg} / \mathrm{kg}$, max: $3.30 \mathrm{mg} / \mathrm{kg}$ ), $\mathrm{Hg}$ (min.: $0.005 \mathrm{mg} / \mathrm{kg}$, $\max : 0.183 \mathrm{mg} / \mathrm{kg}$ ) and $\mathrm{U}$ (min.: $0.012 \mathrm{mg} / \mathrm{kg}$, $\max : 2.01 \mathrm{mg} / \mathrm{kg}$ ). Figure 2 shows the distribution maps of 
concentrations of heavy metals accumulated in mosses sampled in the study area. Concentrations higher than the median value determined for the area are indicated.

Table 2

The medians, mean values and standard deviations $( \pm S D)$ of element concentrations in mosses from the Opole Province [mg/kg, dry mass]

\begin{tabular}{|c|c|c|c|c|c|c|c|}
\hline Element & Median & Mean & \pm SD & Element & Median & Mean & \pm SD \\
\hline $\mathrm{Na}$ & 333 & 422 & 284 & $\mathrm{Mo}$ & 0.28 & 0.40 & 0.36 \\
\hline $\mathrm{Mg}$ & 2340 & 2769 & 1407 & $\mathrm{I}$ & 1.23 & 1.54 & 0.96 \\
\hline $\mathrm{Al}$ & 1120 & 1755 & 2127 & $\mathrm{Ag}$ & 0.077 & 0.083 & 0.037 \\
\hline $\mathrm{Cl}$ & 371 & 522 & 367 & $\mathrm{Cd}$ & 0.056 & 0.081 & 0.068 \\
\hline $\mathrm{K}$ & 10000 & 10711 & 4415 & $\mathrm{Sb}$ & 0.26 & 0.27 & 0.14 \\
\hline $\mathrm{Ca}$ & 4070 & 4677 & 2102 & $\mathrm{Ba}$ & 43 & 48 & 31 \\
\hline $\mathrm{Sc}$ & 0.21 & 0.37 & 0.49 & $\mathrm{Cs}$ & 0.18 & 0.31 & 0.26 \\
\hline $\mathrm{V}$ & 2.0 & 2.9 & 3.4 & $\mathrm{La}$ & 0.8 & 1.4 & 1.7 \\
\hline $\mathrm{Cr}$ & 2.8 & 4.1 & 3.3 & $\mathrm{Ce}$ & 2.0 & 3.1 & 3.8 \\
\hline $\mathrm{Mn}$ & 285 & 433 & 429 & $\mathrm{Nd}$ & 0.54 & 0.58 & 0.24 \\
\hline $\mathrm{Fe}$ & 706 & 995 & 970 & $\mathrm{Sm}$ & 0.10 & 0.21 & 0.32 \\
\hline $\mathrm{Ni}$ & 2.4 & 2.8 & 1.8 & $\mathrm{Eu}$ & 0.030 & 0.040 & 0.022 \\
\hline $\mathrm{Co}$ & 0.5 & 1.2 & 3.3 & $\mathrm{~Tb}$ & 0.019 & 0.032 & 0.045 \\
\hline $\mathrm{Zn}$ & 48 & 56 & 22 & $\mathrm{Yb}$ & 0.10 & 0.15 & 0.20 \\
\hline $\mathrm{As}$ & 0.5 & 0.8 & 1.0 & $\mathrm{Hf}$ & 0.23 & 0.43 & 0.61 \\
\hline $\mathrm{Se}$ & 0.195 & 0.201 & 0.073 & $\mathrm{Ta}$ & 0.024 & 0.040 & 0.049 \\
\hline $\mathrm{Br}$ & 2.3 & 2.5 & 1.0 & $\mathrm{~W}$ & 0.16 & 0.18 & 0.11 \\
\hline $\mathrm{Rb}$ & 15 & 18 & 13 & $\mathrm{Au}$ & 0.02 & 0.36 & 0.81 \\
\hline $\mathrm{Sr}$ & 15 & 18 & 10 & $\mathrm{Hg}$ & 0.009 & 0.040 & 0.058 \\
\hline $\mathrm{Zr}$ & 7 & 14 & 19 & $\mathrm{~Pb}$ & 16.4 & 15.5 & 8.8 \\
\hline $\mathrm{Nb}$ & 0.39 & 0.49 & 0.37 & $\mathrm{Th}$ & 0.18 & 0.33 & 0.40 \\
\hline$* \mathrm{~Pb}$ contents were determined by AAS & $\mathrm{U}$ & 0.08 & 0.33 & 0.54 \\
\hline
\end{tabular}

The results presented in Figure 2 show that the study area is affected by various emission sources. The areas located to the north-east of Opole are relatively less polluted with heavy metals, which is exemplified by the distribution of $\mathrm{Cr}, \mathrm{Ni}$ and $\mathrm{Co}$ on the maps. Zinc is an exception. The main source of zinc emissions in the area covered by the research are cement plants located in Opole and Gorazdze (a village situated approximately $20 \mathrm{~km}$ to the south-east of Opole). The nature of the emissions of arsenic (whose main emission sources are metallurgical industry and burning of fossil fuels) is dispersed. The distribution of lead pollution shows that lead probably comes from two main sources. The northern part of the Province may be affected by urban emissions. It is likely that high pollution with $\mathrm{Cr}$, $\mathrm{Cd}, \mathrm{Pb}, \mathrm{Hg}$, and $\mathrm{U}$ in the south of the Opole Province is due to emissions from the Rybnik Coal Basin adjacent to the Opole Province. The cross-border transport of pollutants from Ostrava and Karvina Coal Basin in the Czech Republic is also of relevance. The local sources of deposited contaminants, also located in rural areas, can be difficult to identify [17]. 

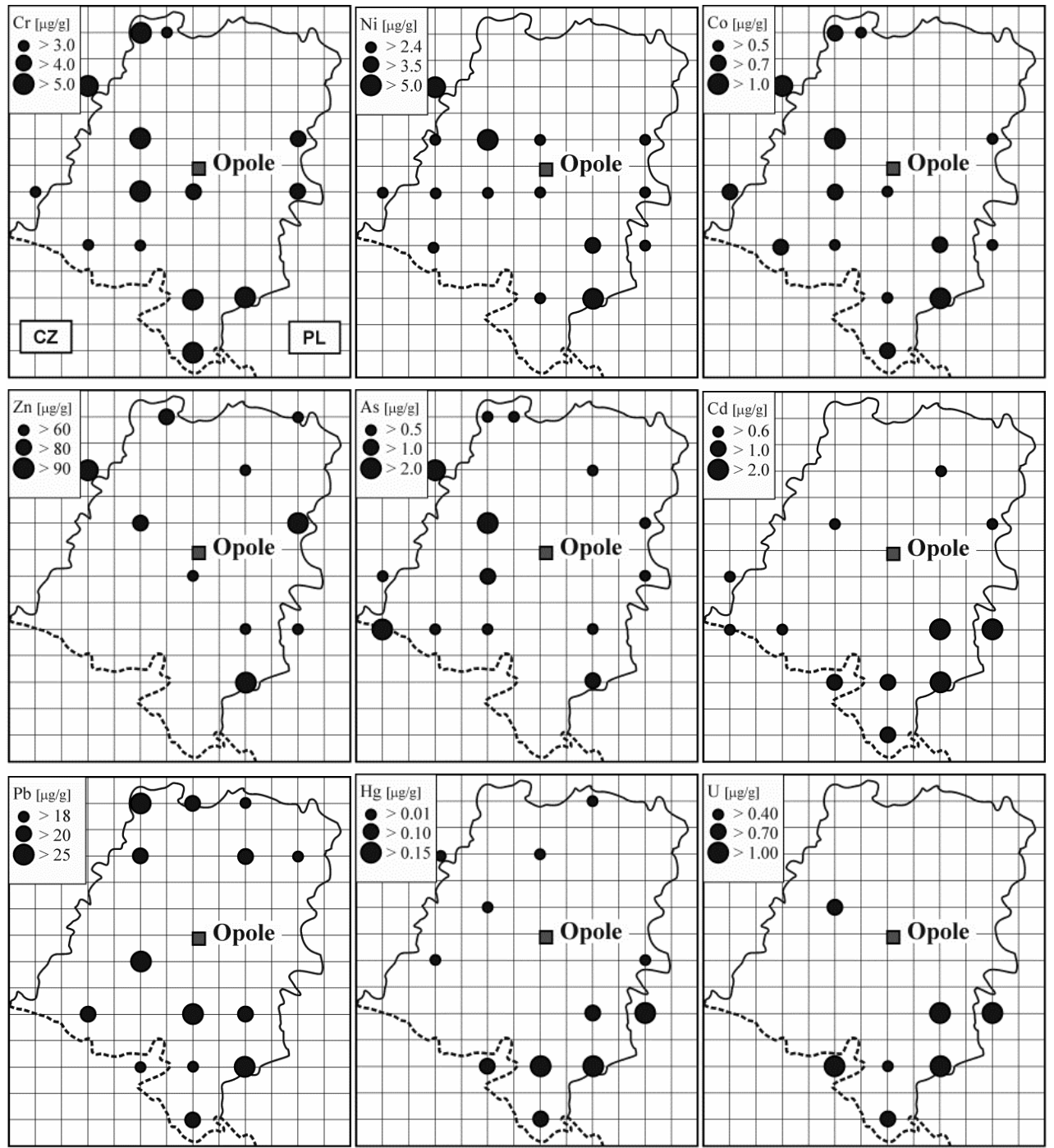

Fig. 2. Distribution maps of concentrations of $\mathrm{Cr}, \mathrm{Ni}, \mathrm{Co}, \mathrm{Zn}, \mathrm{As}, \mathrm{Cd}, \mathrm{Pb}, \mathrm{Hg}$, and $\mathrm{U}$ accumulated in moss samples

Table 3 summarises the results concerning the accumulation of the most frequently determined heavy metals in mosses sampled for testing in the Opole Province in previous years. The results were compared with the mean value determined for the European countries (EU) participating in 2005 in the ICP Vegetation project. 
Concentrations of heavy metals in mosses sampled for testing in the Opole Province in 2005, 2006 and 2011

\begin{tabular}{|c|c|c|c|c|c|c|c|c|c|c|}
\hline Year & $\mathrm{V}$ & $\mathrm{Cr}$ & $\mathrm{Ni}$ & $\mathrm{Zn}$ & $\mathrm{As}$ & $\mathrm{Cd}$ & $\mathrm{Sb}$ & $\mathrm{Pb}$ & $\mathrm{Hg}$ & References \\
\hline $\mathbf{2 0 0 5}(\mathbf{E U})$ & $\mathbf{1 . 1 5}$ & $\mathbf{1 . 8 1}$ & $\mathbf{1 . 7 4}$ & $\mathbf{3 3 . 0}$ & $\mathbf{0 . 2 1}$ & $\mathbf{0 . 1 8}$ & - & $\mathbf{4 . 1 9}$ & $\mathbf{0 . 0 5 5}$ & \multirow{2}{*}[18]{} \\
\hline 2005 & 2.61 & 2.74 & 2.56 & 64.2 & 0.90 & - & 0.36 & - & - & \\
\hline 2006 & 2.62 & 2.94 & 4.95 & 52.0 & 0.66 & 1.25 & 0.56 & 19.6 & - & {$[19,20]$} \\
\hline $2010^{*}$ & - & 1.22 & 1.68 & 58.4 & - & 0.97 & - & 9.30 & 0.045 & {$[21,22]$} \\
\hline 2011 & 2.91 & 4.07 & 2.75 & 55.5 & 0.47 & 0.081 & 0.27 & 15.5 & 0.040 & Present study \\
\hline
\end{tabular}

* The samples of Pleurozium schreberi were collected from the afforested areas in the southern part of the Opole Province

Matrix of rotated factor loadings

Table 4

\begin{tabular}{|c|c|c|c|c|}
\hline & $\mathrm{F} 1$ & $\mathrm{~F} 2$ & F3 & $\mathrm{F} 4$ \\
\hline $\mathrm{Na}$ & 0.54 & 0.69 & 0.31 & 0.10 \\
\hline $\mathrm{Al}$ & 0.87 & 0.38 & 0.04 & 0.21 \\
\hline $\mathrm{Cl}$ & 0.25 & 0.83 & 0.15 & 0.04 \\
\hline $\mathrm{K}$ & 0.16 & 0.84 & -0.19 & 0.21 \\
\hline $\mathrm{Ca}$ & 0.43 & 0.68 & -0.11 & 0.06 \\
\hline $\mathrm{V}$ & 0.89 & 0.33 & 0.10 & 0.23 \\
\hline $\mathrm{Cr}$ & 0.83 & 0.38 & 0.02 & 0.16 \\
\hline $\mathrm{Fe}$ & 0.87 & 0.33 & -0.08 & 0.24 \\
\hline $\mathrm{Ni}$ & 0.81 & 0.37 & 0.07 & 0.05 \\
\hline $\mathrm{Co}$ & 0.20 & 0.36 & 0.73 & -0.07 \\
\hline $\mathrm{Zn}$ & 0.45 & 0.24 & 0.36 & 0.11 \\
\hline As & 0.15 & 0.63 & 0.19 & -0.02 \\
\hline $\mathrm{Se}$ & 0.05 & -0.36 & 0.21 & 0.74 \\
\hline $\mathrm{Br}$ & 0.49 & 0.02 & 0.37 & 0.45 \\
\hline $\mathrm{Sr}$ & 0.54 & 0.70 & 0.00 & 0.07 \\
\hline Mo & 0.11 & -0.04 & 0.90 & -0.21 \\
\hline $\mathrm{I}$ & 0.16 & -0.04 & $\begin{array}{l}0.88 \\
\end{array}$ & 0.13 \\
\hline $\mathrm{Ag}$ & 0.35 & -0.01 & -0.39 & 0.21 \\
\hline $\mathrm{Cd}$ & 0.14 & 0.21 & -0.28 & $\begin{array}{l}0.88 \\
\end{array}$ \\
\hline $\mathrm{Sb}$ & 0.56 & -0.40 & 0.24 & 0.28 \\
\hline $\mathrm{Ba}$ & 0.72 & 0.46 & 0.21 & 0.20 \\
\hline Cs & 0.58 & 0.01 & -0.02 & -0.14 \\
\hline $\mathrm{W}$ & 0.67 & 0.09 & 0.18 & 0.41 \\
\hline $\mathrm{Au}$ & -0.05 & 0.01 & 0.94 & -0.08 \\
\hline $\mathrm{Hg}$ & 0.16 & 0.17 & -0.19 & 0.88 \\
\hline $\mathrm{Th}$ & 0.81 & 0.42 & 0.06 & 0.34 \\
\hline $\mathrm{U}$ & 0.28 & 0.21 & -0.11 & $\mathbf{0 . 8 5}$ \\
\hline var & 7.59 & 4.88 & 3.96 & 3.81 \\
\hline
\end{tabular}

F1, F2, F3 and F4 - factor loading; var - variance [\%]

Numbers in bold correspond to the correlation coefficients with a value over 0.7

The results presented in the Table 3 show that in the period of six years the deposition of arsenic, cadmium and lead clearly decreased (2011 as compared with 2006). The mean concentrations of chromium showed a variable trend. No significant differences in the concentrations of $\mathrm{V}, \mathrm{Zn}$ and $\mathrm{Sb}$ were observed in this period. In the period between 2010 and 2011, no changes in the mean concentrations of mercury accumulated in mosses were observed. It should be noted that each year the samples of mosses were collected from 
different sites, which, in the case of local anomalies, could affect the final result. Except for cadmium and mercury determined in mosses sampled for testing in 2011, the concentrations of other metals were higher than the mean values determined for the area covering the countries participating in the ICP Vegetation programme. The improved air quality as far as the content of $\mathrm{As}, \mathrm{Cd}$ and $\mathrm{Pb}$ is concerned, as demonstrated by the analysis of the chemical composition of mosses sampled for testing in the Opole Province in the period between 2006 and 2011, is confirmed by the results of measurements of the content of these metals in particulate matter (Table 1). This trend was also demonstrated with reference to the European countries participating in the ICP Vegetation programme. In these countries in 2005, as compared to 1990, significantly decreased mean concentrations of arsenic, cadmium, iron, lead and vanadium (52-72\%) as well as copper, nickel and zinc (20-30\%) were observed. The concentrations of mercury (12\%) and chromium (2\%) slightly decreased [18]. The conducted research has confirmed that changes in the concentrations of analytes accumulated in mosses are due to changes in the deposition of these analytes in the areas covered by the research [7].

Also Principal Component Analysis (Factor Analysis) was used to identify and characterise different pollution sources and to point out the most polluted areas. The results of factor analysis are given in Table 4. Factor scores representing the contributions of individual sampling sites to the relevant factor are given in Figure 3.
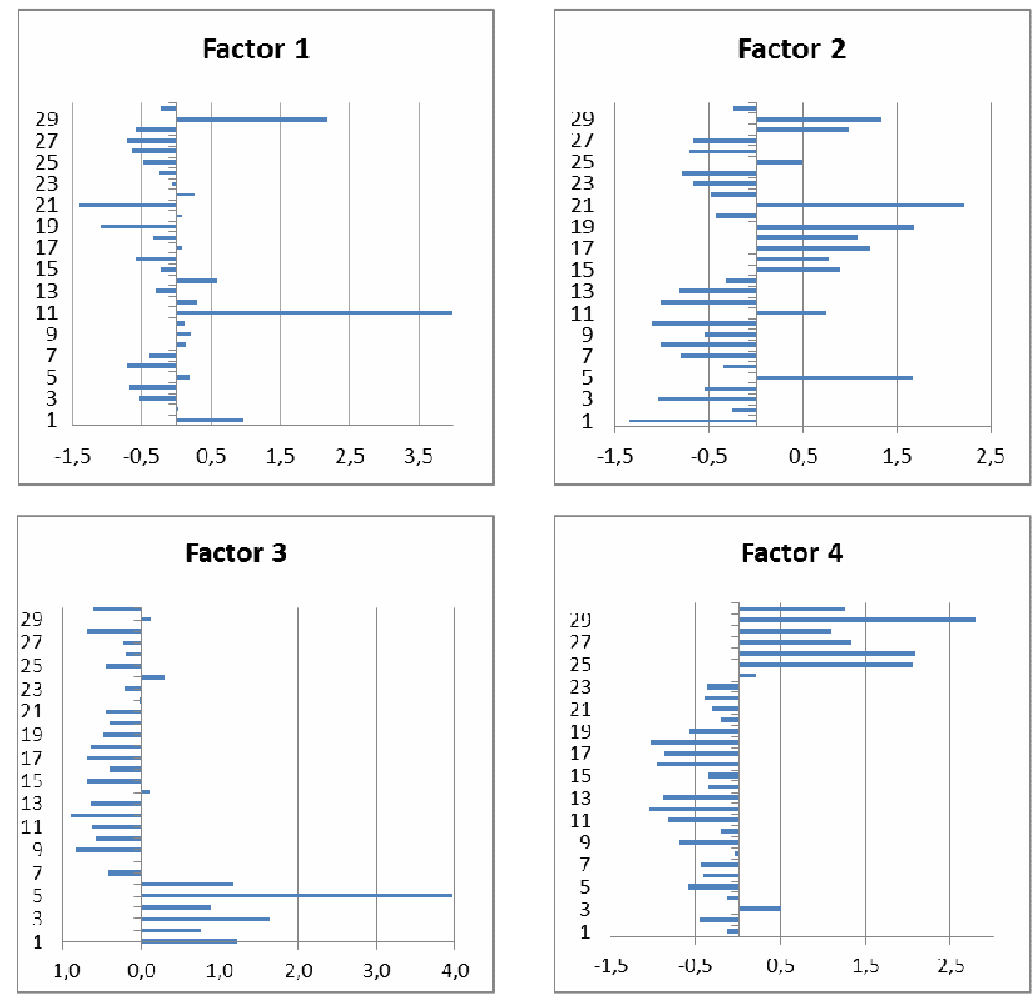

Fig. 3. Plots of factor scores for moss samples from Poland 
Factor 1 (Al, V, Cr, Fe, Ni, Ba, Th) This factor has a typical crustal composition and is influenced by soil particles attached to the moss samples. High pollution at sites 11 and 29 , which are located in agricultural areas, can be a result of matter deposition from industrial sources located in the region of Ostrava (CZ) and Rybnik (PL).

Factor 2 (K, Cl, Sr) Such elemental composition probably reflects the natural content of elements in the feather moss. The samples at 5,19 and 21 sites were collected in small woods surrounded by crop fields.

Factor 3 (Co, Mo, I, Au). This elements indicates anthropogenic origin (except I, which usually is of marine origin). Most probably Mo, $\mathrm{Au}, \mathrm{Co}$ emission are connected with production of zinc, red lead and cadmium oxide, scrap metal processing, and manufacturing of automotive parts in Olawa town (sample site 5). The other polluted sites 1 and 3 are located in small woods surrounded by crop fields, near to national roads. There is no heavy industry facilities in vicinity of the sites.

Factor 4 (Se, Cd, Hg, U). The possible sources of these elements are Rybnik Coal Basin and coal industry in Ostrava region. In these regions mining and processing of coal, steelworks, power plants and other heavy industry, both in Poland and in Czech, are located. Also the glassworks located in south and south-east direction from the study region can deliver elements from this group. Very high pollution level in site 29, located in agricultural region, could be a result of specific atmospheric conditions, which cause transboundary pollutants transport.

\section{Conclusions}

The research results presented in this article constitute part of work that has been conducted since 1990 under the ICP Vegetation project whose objective is to use mosses for the assessment of pollution and dispersion of trace elements, mainly heavy metals, in Europe. They confirmed the trends, observed in recent decades, towards limitation of the deposition of heavy metals, which is inextricably linked to the reduction of emissions.

Principal component analysis (factor analysis) was used to identify possible sources of the elements. The investigated elements can be classified by their main sources as follows: (1) natural sources, such as windblown topsoil dust and essential elements for moss vegetation $(\mathrm{Cl}, \mathrm{K}, \mathrm{Sr})$ and (2) obvious anthropogenic sources: machines production, scrap metal processing or electronic devices construction, can be a reason of $\mathrm{Co}$, Mo, Au release to environment. Elements from Factor 4, ie $\mathrm{Se}, \mathrm{Cd}, \mathrm{Hg}$, and $\mathrm{U}$, could be a result of transboundary transport from distant power plants and heavy industry complexes.

The research has shown that mosses, thanks to their sorption properties, are a good matrix that may be used to assess environmental pollution with heavy metals. Multielements non-destructive NAA makes it possible to determine elements accumulated in mosses in trace quantities so that it is possible to assess the pollution of the areas covered by the research and to identify sources of pollution and pollutant dispersion directions.

\section{Acknowledgments}

The research was conducted under the Environmental Studies in the South of Poland Using Nuclear and Related Analytical Techniques project financed under the research programme of the Polish group at JINR and research centres in Poland in 2011, in line with the decision 03-4-1104-201 112013. 


\section{References}

[1] Smodiš B, Pignata ML, Saiki M, Cortés E, Bangfa N, Markert B, et al. Validation and application of plants as biomonitors of trace element atmospheric pollution - A co-ordinated effort in 14 countries. J Atmos Chem. 2004;49:3-13. DOI:10.1007/s10874-004-1210-2.

[2] Markert B. Definitions and principles for bioindication and biomonitoring of trace metals in the environment. J Trace Elem Med Biol. 2007;21(S1):77-82. DOI: 10.1016/j.jtemb.2007.09.015.

[3] Fraenzle S, Markert B. Metals in biomass: from the biological system of elements to reasons of fractionation and element use. Environ Sci Pollut Res. 2007;6:404-413. DOI: 10.1065/espr2006.12.372.

[4] Markert B, Wuenschmann S, Fraenzle S, Wappelhorst O, Weckert V, Breulmann G, et al. On the road from environmental biomonitoring to human health aspects: monitoring atmospheric heavy metal deposition by epiphytic/epigeic plants: present status and future needs. Int J Environ Pollut. 2008;32:486-498. DOI: 10.1504/IJEP.2008.018412.

[5] Harmens H, Mills G, Hayes F, Jones L, Norris D, Cooper D. ICP Vegetation annual report 2008/2009 (http://icpvegetation.ceh.ac.uk.), accessed 15.11.2013.

[6] Harmens H, Norris D, Mills G. Heavy metals and nitrogen in mosses: spatial patterns in 2010/2011 and long-term temporal trends in Europe. ICP Vegetation Programme Coordination Centre, Bangor, UK: Centre for Ecology and Hydrology; 2013:63.

[7] Harmens H, Norris DA, Koerber GR, Buse A, Steinnes E, Rühling A. Temporal trends (1990-2000) in the concentration of cadmium, lead and mercury in mosses across Europe. Environ Pollut. 2008;151:368-376. DOI: 10.1016/j.envpol.2007.06.043.

[8] Harmens H, Ilyin I, Mills G, Aboal JR, Alber R, Blum O, et al. Country-specific correlations across Europe between modelled atmospheric cadmium and lead deposition and concentrations in mosses. Environ Pollut. 2012;166:1-9. DOI: 10.1016/j.envpol.2012.02.013.

[9] Holy M, Pesch R, Schröder W, Harmens H, Ilyin I, Alber R, et al. First thorough identification of factors associated with $\mathrm{Cd}, \mathrm{Hg}$ and $\mathrm{Pb}$ concentrations in mosses sampled in the European Surveys 1990, 1995, 2000 and 2005. J Atmos Chem. 2012;63:109-124. DOI:10.1007/s10874-010-9160-3.

[10] Suchara I, Maňkovská B, Sucharová J, Florek M, Godzik B, Rabnecz G, et al. Mapping of main sources of pollutants and their transport in the Visegrad space. Part II: Fifty three elements. Project 11007-2006-IVF. Zvolen, Slovak Republic: KLEMO spol. s r.o., (Ltd.); 2007.

[11] Olendrzyński K, Dębski B, Kargulewicz I, Skośkiewicz J, Fudała J, Hławiczka S, et al. Inwentaryzacja emisji zanieczyszczeń powietrza za rok 2001 na potrzeby statystyki krajowej i zobowiązań międzynarodowych w ramach Konwencji w sprawie transgranicznego zanieczyszczenia powietrza na dalekie odległości. Warszawa: IOŚ, Krajowe Centrum Inwentaryzacji Emisji; 2003.

[12] Stan środowiska w województwie śląskim w 2009 r. Biblioteka Monitoringu Środowiska, Katowice: Wojewódzki Inspektorat Ochrony Środowiska w Katowicach; 2010.

[13] Stan środowiska w województwie opolskim w latach 2005-2006. Biblioteka Monitoringu Środowiska, Opole: Wojewódzki Inspektorat Ochrony Środowiska w Opolu; 2007.

[14] Stan środowiska w województwie opolskim w roku 2011. Biblioteka Monitoringu Środowiska, Opole: Wojewódzki Inspektorat Ochrony Środowiska w Opolu; 2012.

[15] Frontasyeva MV. Neutron activation analysis for the Life Sciences. A review. Physics of Particles and Nuclei Letters. 2011;42(2):332-378.

[16] Dmitriev AYu, Pavlov SS. Automatization of quantitative determination of element concentrations in samples by neutron activation analysis at the reactor IBR-2 FLNP JINR. Physics of Particles and Nuclei Letters. 2013;10:58-64.

[17] Olszowski T, Tomaszewska B, Góralna-Włodarczyk K. Air quality in non-industrialised area in the typical Polish countryside based on measurements of selected pollutants in immission and deposition phase. Atmos Environ. 2012;50:139-147. DOI: 10.1016/j.atmosenv.2011.12.049.

[18] Harmens H, Norris DA, Steinnes E, Kubin E, Piispanen J, Alber R, et al. Mosses as biomonitors of atmospheric heavy metal deposition: Spatial patterns and temporal trends in Europe. Environ Pollut. 2010;158:3144-3156. DOI: 10.1016/j.envpol.2010.06.039.

[19] Kłos A, Rajfur M, Wacławek M, Wacławek W, Frontasyeva MV, Pankratova JS. The influence of unidentified pollution sources on the irregularity of biomonitoring tests results. Water Air Soil Pollut. 2008;191:345-352. DOI: 10.1007/s11270-008-9629-8.

[20] Kłos A. Porosty w biomonitoringu środowiska (Lichens in environmental biomonitoring). Opole: Wyd. Uniwersytetu Opolskiego; 2009. 
[21] Kłos A, Rajfur M, Šrámek I, Wacławek M. Use of lichen and moss in assessment of forest contamination with heavy metals in Praded and Glacensis Euroregions (Poland and Czech Republic). Water Air Soil Pollut. 2011;222:367-376. DOI: 10.1007/s11270-011-0830-9.

[22] Kłos A, Rajfur M, Šrámek I, Wacławek M. Mercury concentration in lichen, moss and soil samples collected from the forest areas of Praded and Glacensis Euroregions (Poland and Czech Republic). Environ Monit Assess. 2012;184:6765-6774. DOI: 10.1007/s10661-011-2456-1.

\title{
WYKORZYSTANIE NEUTRONOWEJ ANALIZY AKTYWACYJNEJ W BIOMONITORINGU DEPOZYCJI PIERWIASTKÓW ŚLADOWYCH W WOJEWÓDZTWIE OPOLSKIM
}

\author{
${ }^{1}$ Samodzielna Katedra Biotechnologii i Biologii Molekularnej, Uniwersytet Opolski, Opole, Polska \\ ${ }^{2}$ Zjednoczony Instytut Badań Jądrowych, Dubna, Rosja
}

\begin{abstract}
Abstrakt: Metodą neutronowej analizy aktywacyjnej oznaczono stężenia 42 pierwiastków: $\mathrm{Na}, \mathrm{Mg}, \mathrm{Al}, \mathrm{Cl}, \mathrm{K}, \mathrm{Ca}$, $\mathrm{Sc}, \mathrm{V}, \mathrm{Cr}, \mathrm{Mn}, \mathrm{Fe}, \mathrm{Ni}, \mathrm{Co}, \mathrm{Zn}, \mathrm{As}, \mathrm{Se}, \mathrm{Br}, \mathrm{Rb}, \mathrm{Sr}, \mathrm{Zr}, \mathrm{Nb}, \mathrm{Mo}, \mathrm{I}, \mathrm{Ag}, \mathrm{Cd}, \mathrm{Sb}, \mathrm{Ba}, \mathrm{Cs}, \mathrm{La}, \mathrm{Ce}, \mathrm{Nd}, \mathrm{Sm}, \mathrm{Eu}, \mathrm{Tb}, \mathrm{Yb}$, $\mathrm{Hf}, \mathrm{Ta}, \mathrm{W}, \mathrm{Au}, \mathrm{Hg}$, Th i U, zakumulowanych w mchach pobranych do badań we wrześniu i w październiku 2011 roku na terenie województwa opolskiego (południowa Polska). Próbki różnych gatunków mchów pobierano w bliskiej odległości od miejsc przecięcia linii siatki kartograficznej naniesionych na mapę województwa. Odległości pomiędzy punktami wynosiły ok. $20 \mathrm{~km}$. Analiza wyników badań umożliwiła wskazanie miejsc zwiększonej depozycji zanieczyszczeń wraz ze wskazaniem potencjalnych źródeł ich emisji. Wykazano m.in. zwiększoną zawartość Cr, Cd, Hg i U zakumulowanych w próbkach mchów pobranych do badań na obszarach rolniczych położonych na południu województwa. Stwierdzono, że potencjalnym źródłem emisji mogą być uprzemysłowione tereny Rybnickiego i Ostrawsko-Karwińskiego Zagłębia Węglowego. Badania prowadzono w ramach projektu Environmental studies in the South of Poland using nuclear and related analytical techniques.
\end{abstract}

Słowa kluczowe: neutronowa analiza aktywacyjna (NAA), mchy, biomonitoring, południowa Polska 